\title{
Pleural Desmoplastic Mesothelioma
}

National Cancer Institute

\section{Source}

National Cancer Institute. Pleural Desmoplastic Mesothelioma. NCI Thesaurus. Code C45664.

Malignant mesothelioma that arises from the pleura and is characterized by the presence of dense collagenized stroma occupying at least 50\% of the tumor. The malignant cells are arranged in a vague storiform pattern. 